Studi Akuntansi \& Keuangan Indonesia

\title{
Analisis Kecurangan pada Pengelolaan Dana Desa dalam Perspektif Fraud Hexagon
}

\author{
Desviana, Yesi Mutia Basri*, Nasrizal \\ Program Studi Akuntansi, Fakultas Ekonomi dan Bisnis, Universitas Riau \\ Kampus Bina Widya KM. 12,5, Simpang Baru, Kec. Tampan, Kota Pekanbaru, Riau 28293
}

\section{Keywords:}

Capability, Ego, Fraud, Oportunity, Razionalitation, Stimulus

\section{Kata Kunci:}

Kompetensi, Ego,

Kecurangan,

Kesempatan,Rasionalisasi,

Tekanan

\section{*Corresponding author: yesimutia@gmail.com}

\begin{abstract}
:
This research aims to examine and analyze the factors that influence fraud in the management of village funds from the perspective of hexagon theory in the Rokan Hulu Regency in Riau Province. The population in this study were all village officials in Rokan Hulu Regency, Riau Province. This study uses a probability sampling method with a simple random sampling technique. The research hypothesis testing was carried out with a Partial Least Square (PLS) based Structural Equation Model (SEM) approach. Based on the results of research, only stimulus (obedience pressure), capability (competence), collusion (unethical act), opportunity ( Internal control) affect fraud. Meanwhile, razionalitation (organizational culture) and ego (leadership style) do not affect fraud. This research was only carried out within the scope of the local government of the Rokan Hulu district, so the results of this study were more representative of the situation locally. The results of this study confirm that several factors can cause fraud to occur, and therefore village officials should jointly improve the quality of village fund management.
\end{abstract}

\section{Abstrak:}

Penelitian ini bertujuan untuk menguji dan menganalisis faktorfaktor yang berpengaruh terhadap fraud dalam pengelolaan dana desa dalam perspektif Teori Heksagon di Kabupaten Rokan Hulu Provinsi Riau. Populasi dalam penelitian ini ada seluruh perangkat desa Kabupaten Rokan Hulu, Provinsi Riau dengan metode probability sampling teknik simple random sampling. Pengujian hipotesis penelitian dilakukan dengan pendekatan Structural Equation Model (SEM) berbasis Partial Least Square (PLS). Berdasarkan hasil penelitian diperoleh hasil stimulus (tekanan ketaatan), capability (kompetensi), collusion (perbuatan tidak etis), oportunity ( keefektifan sistem pengendalian internal). Sementara, razionalitation (budaya organisasi) dan ego (gaya kepemimpinan) tidak berpengaruh terhadap fraud. Penelitian ini hanya dilakukan di lingkup pemerintah daerah kabupaten Rokan Hulu, sehingga hasil penelitian ini lebih menggambarkan situasi secara lokal. Hasil penelitian ini menegaskan bahwa ada beberapa faktor yang dapat menyebabkan tindakan kecurangan terjadi,oleh sebab itu sebaiknya aparatur desa secara bersama-sama dapat meningkatkan kualitas pengelolaan dana desa. 


\section{Pendahuluan}

Secara Nasional, pemerintah telah mengalokasikan anggaran dana desa dengan nilai yang cukup fantastis untuk sebuah program/kebijakan yang baru. Berdasarkan data pada Kementerian Keuangan RI (Nota Keuangan), jumlah dana desa yang telah dianggarkan oleh pemerintah dalam 3 (tiga) tahun terakhir adalah sebesar Rp.127,75 Triliun. Dengan rincian sebagai berikut: pada tahun 2015 sebesar Rp.20,77 Triliun, tahun 2016 sebesar Rp.46,98 Triliun, dan tahun 2017 sebesar Rp.60 Triliun. Tetapi, dana desa tersebut tidak dikelola sebagaimana mestinya, pengelolaan dana desa tersebut indentik dengan penyalahgunaan dalam pengelolaan, hal ini dibuktikan dari pernyataan “Outlook Dana Desa 2018” yang dikeluarkan oleh Indonesia Corruption Watch (ICW) bahwa hasil pemantauan ICW, pada tahun 2015 - 2017 kasus penyalahgunaan kecurangan di desa semakin meningkat. Pada tahun 2015 mencapai 17 kasus dan meningkat menjadi 41 kasus pada tahun 2016. Lonjakan lebih dari dua kali lipat kemudian terjadi pada tahun 2017 dengan 96 kasus. Total kasus kecurangan yang ditemukan sebanyak 154 kasus. Banyaknya kasus kecurangan dana desa ini membuat kerugian dalam jumlah yang besar.

Dalam penelitian ini, peneliti akan melihat kecurangan dari teori The Fraud Hexagon. Peneliti menggunakan teori baru ini karena seiring dengan perkembangan waktu, teori fraud juga pasti akan mengalami perkembangan. Teori Hexagon merupakan pengembangan teori pentagon yang dianggap belum dapat melengkai faktor yang dapat mempengaruhi fraud. Teori yang dikembangkan oleh Vousinas (2019) dari National Technical University of Athens ini berasal dari pengembangan teori pentagon (S.C.O.R.E), yang terdiri dari Stimulus (pressure), Capability (competence), Opportunity, Rationalization, dan Ego (arrogance). Kemudian, model memperbarui dan mengadaptasi teori tersebut dari kasus fraud yang ada dengan menambahkan Collusion, sehingga model terbaru dari fraud adalah S.C.C.O.R.E. Teori ini berpendapat bahwa kolusi secara tidak sengaja dapat pula menjadi motivasi fraud. Hal inilah yang menjadi perbedaan antara penelitian ini dengan penelitian sebelum-sebelumnya. Pada penelitian ini, peneliti akan menggunakan sebuah teori baru dari fraud yaitu The Fraud Hexagon, dimana penelitian sebelumnya hanya sebatas teori pentagon. Seperti 
Studi Akuntansi \& Keuangan Indonesia

penelitian yang dilakukan oleh Ulfah et al. (2017), dan Danuta (2017) yang masih menggunakan teori pentagon.

Berdasarkan fenomena, teori yang berkembang, serta penelitian sebelumnya (Ulfah et al., 2017; Danuta, 2017) maka peneliti tertarik melakukan penelitian untuk melihat pengaruh faktor-faktor kecurangan yang meliputi Stimulus (pressure), Capability (competence), Collusion, Opportunity, Rationalization, dan Ego (arrogance). Pada Pengelolaan Dana Desa dengan menggunakan Perspektif The Fraud Hexagon's Theory. Penelitian ini diharapkan dapat berkontribusi dalam pengembangan ilmu akuntansi, dikarenakan penelitian ini merupakan pengembangan dari penelitian-penelitian terdahulu dan menggunakan teori baru, yaitu teori heksagon.

\section{Telaah Literatur dan Pengembangan Hipotesis}

\section{Fraud dan Teori Heksagon}

Menurut The Association of Certified Fraud Examiners (ACFE, 2016), fraud adalah perbuatan-perbuatan yang melawan hukum yang dilakukan dengan sengaja untuk tujuan tertentu (manipulasi atau memberikan laporan keliru terhadap pihak lain) dilakukan orang-orang dari dalam atau luar organisasi untuk mendapatkan keuntungan pribadi ataupun kelompok yang secara langsung atau tidak langsung merugikan pihak lain. Association of Certified Fraud Examiners (ACFE) membuat kategori kecurangan (fraud) yang dikenal dengan istilah fraud tree. Di dalam fraud tree, kecurangan dibagi menjadi sebuah kategori, sub kategori dan bagian dari sub kategori. Tiga kategori utama yaitu korupsi (corruption), penyalahgunaan aset (asset misappropriation), dan penyimpangan laporan keuangan (fradulent statement) (Singleton et al., 2006).

Kecurangan terjadi dalam beberapa sektor, termasuk sektor desa, seperti kecurangan dalam pengelolaan dana desa. Dana desa yang pada awalnya untuk meningkatkan desa mandiri tersebut tidak dikelola sebagaimana mestinya, pengelolaan dana desa tersebut identik dengan penyalahgunaan dalam pengelolaan, hal ini dibuktikan dari pernyataan “Outlook Dana Desa 2018" yang dikeluarkan oleh Indonesia Corruption Watch (ICW) dalam buku dana desa yang dikeluarkan oleh Kementrian Keuangan. Hasil pemantauan ICW, pada tahun 2015 - 2017 kasus penyalahgunaan di desa semakin 
Studi Akuntansi \& Keuangan Indonesia

meningkat. Pada tahun 2015 mencapai 17 kasus dan meningkat menjadi 41 kasus pada tahun 2016. Lonjakan lebih dari dua kali lipat kemudian terjadi pada tahun 2017 dengan 96 kasus. Total kasus kecurangan yang ditemukan sebanyak 154 kasus, kecurangan yang terjadi seperti korupsi sampai penyalahgunaan aset.

Kecurangan yang terjadi dapat dipengaruhi oleh beberapa faktor, pada penelitian ini, peneliti akan mengambil faktor dari teori yang dikembangkan oleh Vousinas (2019) dari National Technical University of Athens, teori ini berasal dari pengembangan teori pentagon. Teori yang dikembangkan oleh Vousinas (2019) ini berasal dari pengembangan teori pentagon (S.C.O.R.E), yang terdiri dari Stimulus, Capability, Opportunity, Rationalization, dan Ego. Kemudian, Vousinas memperbarui dan mengadaptasi teori tersebut dari kasus fraud yang ada dengan menambahkan Collusion. Teori ini berpendapat bahwa kolusi secara tidak sengaja dapat pula menjadi pengembang fraud yang ada di dalam organisasi. Fraudster menggunakan kemampuan mereka untuk mengambil keuntungan dari posisi orang lain dan memanfaatkan korban (Vousinas,2019).

Penelitian ini merupakan pengembangan dari teori- teori fraud sebelumnya, seperti penelitian dari Hartoyo (2016) berjudul “Analisis Pentagon Fraud dalam Mendeteksi Fraudulent Financial Reporting”. Hasil dari penelitiannya menunjukkan bahwa opportunity berpengaruh terhadap fraudulent financial reporting. Sedangkan pressure, ratinalizayion, competency dan arrogance tidak berpengaruh terhadap fraudulent financial reporting.

\section{Pengembangan Hipotesis}

\section{Stimulus (Tekanan) dan Fraud}

Tekanan menjadi salah satu alasan bagi manajemen dan pegawai lainnya dalam melakukan fraud. Tekanan dapat datang dalam berbagai bentuk, keuangan maupun non-keuangan. Tekanan dapat terjadi dikarenakan adanya tujuan yang tidak realistik dari pihak manajemen kepada pegawainya atau pemilik kepada manajemen agar memenuhi kemauan pemilik. Oleh karena itu dalam penelitian ini, stimulus diproksikan dengan variabel tekanan ketaatan (Tuanakotta, 2010).

Teori ketaatan menyatakan bahwa individu akan melakukan tindakan yang diperintahkan oleh atasannya meskipun hal tersebut tidak sesuai dengan prinsip yang dimilikinya. Hal ini disebabkan 
Studi Akuntansi \& Keuangan Indonesia

oleh keberadaan kekuasaan atau otoritas yang merupakan bentuk dari legitimate power. Paradigma ketaatan pada kekuasaan ini dikembangkan oleh Milgram (1974) dalam Mayhew dan Murphy (2014), dalam teorinya dikatakan bahwa bawahan yang mengalami tekanan ketaatan dari atasan akan mengalami perubahan psikologis. Perubahan perbuatan ini terjadi karena bawahan tersebut merasa menjadi agen dari sumber kekuasaan. Mayhew dan Murphy (2014) menemukan bahwa dengan adanya otoritas atasan akan meningkatkan perbuatan kecurangan pelaporan. Rafinda (2013) juga menyebutkan bahwa perilaku atasan atau tekanan yang diberikan atasan terbukti dapat mempengaruhi perilaku seluruh bawahannya. Atasan yang berperilaku etis akan menuntun bawahannya untuk berperilaku etis dan sebaliknya, Rafinda (2013) berkesimpulan bahwa tekanan yang diterima oleh bawahaan akan meningkatkan kecurangan yangg terjadi perusahaan. Selain itu, Sofyani dan Pramita (2013) juga menemukan bahwa kondisi dimana terdapat tekanan ketaatan untuk melakukan kecurangan cenderung akan menjadikan seseorang bertindak memanipulasi laporan.

\section{H1. Tekanan Ketaatan berpengaruh positif terhadap fraud.}

\section{Capability (Kemampuan) dan Fraud}

Kapabilitas (Capability) merupakan kemampuan pegawai dalam dalam mengembangkan organisasinya dan mampu mengendalikan situasi sosial yang mampu mendatangkan keuntungan baginya (Zimbelman et al., 2014). Berdasarkan (Zimbelman et al., 2014) capability akan diproksikan dengan kompetensi yang ada pada aparat desa. Menurut UU No 13 tahun 2003 pasal 1 (10) kompetensi merupakan kemampuan melaksanakan pekerjaan dilandasi keterampilan, pengetahuan serta sikap kerja. Berdasarkan penelitian yang dilakukan oleh Sihombing dan Rahardjo (2014) mengatakan bahwa kompetensi yang diukur dengan tingkat kemampuan, pengetahuan dan attitude dapat mempengaruhi kecurangan yang terjadi. Hasil penelitiannya ditemukan bahwa apabila seorang pegawai memiliki kompetensi yang tidak memadai akan meningkatkan resiko kecurangan, hal ini dikarenakan pegawai tersebut kurang dalam attitude untuk mengetahui perbuatan baik atau buruk yang sedang dilakukkannya. Begitu juga penelitian yang dilakukan oleh Adnyani et al. (2014) yang menyatakan bahwa jika seseorang karyawan akuntansi tidak memiliki kemampuan akuntansi yang 
Studi Akuntansi \& Keuangan Indonesia

baik, maka itu akan menjadi kesempatan untuk dilakukannya penyimpangan laporan keuangan oleh pihak-pihak yang berkepentingan.

H2. Kompetensi berpengaruh negatif terhadap fraud.

\section{Collusion (Kolusi) dan Fraud}

Istilah kolusi diambil dari bahasa latin collusio yang berarti kesepakatan rahasia, persekongkolan untuk melakukan perbuatan tidak etis (Sihombing dan Rahardjo, 2014). Perbuatan tidak etis itu mungkin berupa delik (tindak pidana), mungkin juga tidak. Kolusi untuk berbohong bukanlah masuk dalam ruang lingkup hukum pidana. Karena didasari pada teori tersebut kolusi dapat diproyeksikan sebagai perbuatan tidak baik atau perilaku tidak etis.

Wilpopo (2006) menyatakan bahwa berbagai kecurangan akuntansi yang dilakukan oleh perusahaan Enron, WorldCom, Xerox, dan lain-lain di USA dikarenakan perilaku tidak etis manajemen perusahaan. Demikian pula CIMA (2002) dalam Wilopo (2006) berpendapat bahwa perusahaan dengan standar etika yang rendah memiliki risiko kecurangan akuntansi yang tinggi. Berbagai kajian dan penyampaian fakta, seperti oleh Beaulieu \& Reinstein (2010) menunjukkan bahwa perilaku tidak etis dalam bentuk penyalahgunaan wewenang dan kekuasaan, kedudukan, dan sumberdaya perusahaan, mendorong manajemen melakukan kecurangan akuntansi.

\section{H3. Perbuatan tidak etis berpengaruh positif terhadap fraud.}

\section{Opportunity (Kesempatan) dan Fraud}

Menurut Montgomery et al. (2002) kesempatan yaitu peluang yang menyebabkan pelaku secara leluasa dapat menjalankan aksinya yang disebabkan oleh pengendalian internal yang lemah, ketidakdisplinan, kelemahan dalam mengakses informasi dan sikap apatis. Hal yang paling menonjol di sini adalah dalam hal pengendalian internal. Pengendalian internal yang tidak baik akan memberi peluang orang untuk melakukan kecurangan. Oleh sebab itu dalam penelitian ini, opportunity di proksikan dengan variabel keefektifan sistem pengendalian internal.

Sistem pengendalian internal yang efektif diharapkan mampu mengurangi adanya tindakan menyimpang yang dilakukan oleh manajemen. Salah satu contoh tindakan menyimpang yaitu kecenderungan melakukan kecurangan akuntansi. Peluang yang besar membuat kecenderungan 
Studi Akuntansi \& Keuangan Indonesia

kecurangan akuntansi lebih sering terjadi. Peluang tersebut dapat dikurangi dengan sistem pengendalian internal yang baik. Pengendalian internal yang semakin baik dapat mengurangi atau bahkan menutup peluang untuk melakukan kecenderungan kecurangan akuntansi (Mustika et al.,2016).

H4. Keefektifan sistem pengendalian internal berpengaruh negatif terhadap fraud.

\section{Rationalization dan Fraud}

Rasionalisasi menjadi elemen penting dalam terjadinya fraud, dimana pelaku mencari pembenaran atas perbuatannya. Rasionalisasi merupakan bagian fraud yang paling sulit diukur (Skousen et al., 2009). Rasionalisasi menjadi elemen penting dalam terjadinya fraud, dimana pelaku mencari pembenaran atas tindakannya, seperti alasannya untuk membahagiakan keluarga dan orangorang yang dicintainya. Dalam penelitian ini, rationalization diproksikan dengan variabel budaya organisasi berdasarkan teori yang dijelaskan oleh Skousen et al (2009) yang mendefinisikan budaya organisasi sebagai sistem dan nilai-nilai yang diyakini semua anggota organisasi, yang dipelajari, diterapkan serta dikembangkan secara berkesinambungan dan dapat dijadikan acuan berperbuatan dalam organisasi untuk mencapai tujuan organisasi yang telah ditetapkan.

Rendahnya budaya organisasi yang diterapkan dalam suatu organisasi dapat mengakibatkan seseorang memiliki keinginan besar melakukan kecurangan karena peran budaya organisasi sangat penting, yaitu sebagai penentu arah, mana yang boleh dilakukan dan mana yang tidak boleh dilakukan. Hasil penelitian terdahulu yang dilakukan oleh Zulkarnain (2013) dan Wulandari dan Zaky (2015) menemukan bahwa budaya etis organisasi berpengaruh terhadap terjadinya fraud di pemerintahan, rendahnya budaya organisasi yang diterapkan dalam suatu organisasi dapat mengakibatkan seseorang memiliki keinginan besar melakukan kecurangan karena peran budaya organisasi sangat penting, yaitu sebagai penentu arah, mana yang boleh dilakukan dan mana yang tidak boleh dilakukan, bagaimana mengelola dan mengalokasikan sumber daya organisasi serta sebagai alat untuk menghadapi masalah dan peluang dari lingkungan internal dan eksternal.

H5. Budaya organisasi berpengaruh negatif terhadap fraud.

Ego (Arrogance) dan Fraud 
Studi Akuntansi \& Keuangan Indonesia

Arrogance merupakan perilaku superioritas dan hak atau keserakahan pada pelaku kejahatan yang mempercayai bahwa kebijakan perusahaan dan prosedur tidak diterapkan kepadanya (Horwath, 2011). Dalam penelitian ini, arrogance di proksikan dengan variabel gaya kepemimpinan sesuai dengan konsep dari Horwath (2011). Teori peran menjelaskan mengenai interaksi antar individu yang menduduki peran tertentu dalam suatu organisasi. Kepala desa sebagai pemimpin dalam pemerintahan desa berperan dalam merencanakan, mengatur, mengorganisasikan, dan menentukan arah dan tujuan organisasi. Dengan demikian, diharapkan dapat meningkatkan motivasi kerja perangkat desa dan membawa pemerintahan desa mencapai akuntabilitas pengelolaan dana desa (Pramudita, 2013). Hasil penelitian terdahulu yang dilakukan oleh Sumbayak (2017) juga menemukan bahwa gaya kepemimpinan berpengaruh terhadap terjadinya fraud di pemerintahan, semakin bagus peran yang dijalankan oleh kepala desa maka akan mengurangi terjadinya fraud di kantor desa tersebut.

H6. Gaya kepemimpinan berpengaruh negatif terhadap fraud.

\section{Metode Penelitian}

\section{Populasi dan Sampel}

Populasi penelitian ini adalah seluruh perangkat desa di Kabupaten Rokan Hulu, Provinsi Riau yang terdiri dari kepala desa, sekretaris desa dan pelaksana teknis, seperti bagian pemerintah, bagian pembangunan, bagian kesejahteraan rakyat, bagian keuangan dan bagian umum. Dalam penelitian ini penulis menggunakan probability sampling karena dalam penelitian ini setiap anggota populasi memiliki peluang yang sama untuk dipilih menjadi anggota sampel dengan menggunakan teknik pengambilan sampel simple random sampling. Pada akhirnya yang menjadi responden dalam penelitian ini sebanyak 246 responden yang terdiri dari kepala desa, sekretaris desa, pelaksana teknis bagian keuangan, pelaksana teknis bagian kesejahteraan rakyat, dan pelaksana teknis bagian umum. Namun data yang dapat diolah sebesar 124 responden dari 246 data responden yang terkumpul.

\section{Analisis data}


Penelitian ini menggunakan teknik pengumpulan data primer dilakukan dengan metode survei yaitu metode pengumpulan data primer yang menggunakan pernyataan tertulis. Metode survei yang digunakan adalah dengan cara menyebarkan kuisioner kepada responden dalam bentuk pernyataan tertulis. Survey dilakukan pada Bulan Maret hingga Mei 2020. Analisis data yang digunakan dalam penelitian ini adalah dengan pendekatan analisis SEM (Structural Equation Model) berbasis PLS (Partial Least Square) dengan menggunakan software Smart Pls versi 3.

\section{Operasionalisasi Variabel dan Model Penelitian}

Variabel fraud/kecurangan diukur dengan item pertanyaan/indikator yang dikembangkan dari jenis-jenis kecurangan menurut ACFE (2016) diantaranya: kecurangan laporan keuangan, penyalahgunaan asset dan korupsi. Variabel tekanan ketaatan (X1) diukur menggunakan instrumen kuesioner yang terdiri dari 5 item pertanyaan, dengan indikator yaitu personal pressure, employment pressure, external pressure (Yendrawakti dan Mukti, 2015). Kompetensi (X2), pengukuran variabel ini diadaptasi dari indikator yang dijelaskan oleh Edison et al. (2016), yaitu : pengetahuan, kemampuan dan sikap/attitude. Perbuatan tidak etis (X3), indikator variabel ini diambil dari penelitian yang dilakukan Tang dan Chiu (2003) yaitu perbuatan manajemen yang menyalahgunakan kedudukan (abuse position), perbuatan manajemen yang menyalahgunakan sumber daya organisasi (abuse resources), perbuatan manajemen yang menyalahgunakan kekuasaan (abuse power) dan perbuatan manajemen yang tidak berbuat apa-apa (no action).

Variabel berikutnya yakni keefektifan Sistem Pengendalian Intern (SPI) (X4). COSO (2013) menyatakan mengenai unsur-unsur pengendalian internal sebagai berikut : lingkungan pengendalian, penilaian risiko, kegiatan pengendalian, informasi dan komunikasi dan pemantauan pengendalian intern. Varibel budaya organisasi (X5), indikator budaya organisasi menurut Robbins \& Timothy (2011) yaitu; attention to detail (perhatian terhadap detail), outcome orientation (orientasi hasil), people orientation (orientasi individu), team orientation (orientasi terhadap Tim) dan aggressiveness (agresivitas). Gaya Kepemimpinan (X6), indikator gaya kepemimpinan yaitu : kepemimpinan direktif, kepemimpinan suportif, kepemimpinan partisipatif dan kepemimpinan berorientasi prestasi. Secara rinci, variabel dan indikator penelitian dijabarkan pada kuesioner di lampiran 1. 
Berdasarkan penjelasan di atas, maka dapat dirumuskan model penelitian sebagai berikut:

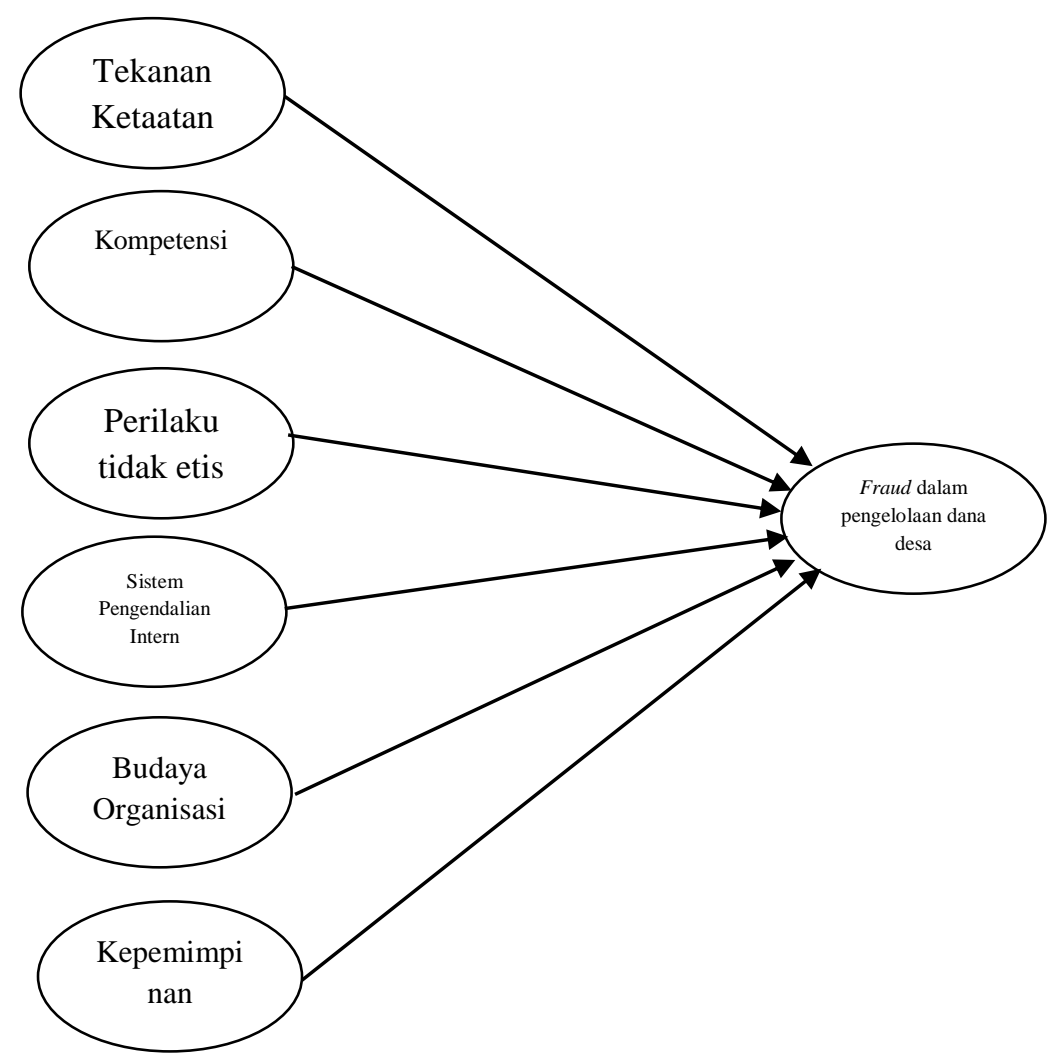

Gambar 1. Model Penelitian

\section{Hasil dan Diskusi}

\section{Demografi Responden}

Tabel 1 berikut memperlihatkan data demografi responden.

Tabel 1. Demografi Responden

\begin{tabular}{|c|l|c|c|}
\hline & \multicolumn{1}{|c|}{ Item } & Jumlah & Persentase \\
\hline \multirow{4}{*}{ Umur } & $21-30$ Tahun & 11 & $9 \%$ \\
\cline { 2 - 4 } & $31-40$ Tahun & 52 & $42 \%$ \\
\cline { 2 - 4 } & $41-50$ Tahun & 38 & $30 \%$ \\
\cline { 2 - 4 } & $\geq 50$ Tahun & 23 & $19 \%$ \\
\hline \multirow{3}{*}{ Jenis Kelamin } & Pria & 68 & $55 \%$ \\
\cline { 2 - 4 } & Perempuan & 56 & $45 \%$ \\
\hline \multirow{3}{*}{ Pendidikan } & D3 & 22 & $17,8 \%$ \\
\cline { 2 - 4 } & Sarjana (S1) & 79 & $63,7 \%$ \\
\cline { 2 - 4 } & Sarjana (S2) & 23 & $18,5 \%$ \\
\hline \multirow{3}{*}{$\begin{array}{c}\text { Pengalaman } \\
\text { Bekerja }\end{array}$} & $3-10$ Tahun & 29 & $23,4 \%$ \\
\cline { 2 - 4 } & $11-20$ Tahun & 71 & $57,2 \%$ \\
\cline { 2 - 4 } & $\geq 21$ Tahun & 24 & $19,4 \%$ \\
\hline
\end{tabular}


Dari 124 responden, berdasarkan tingkat usia paling banyak adalah pegawai yang berusia $31-40$ tahun yaitu sebanyak 52 orang atau $42 \%$. Hal ini menggambarkan bahwa SDM di setiap kantor desa di Rokan Hulu tersebut, masih tergolong pada usia produktif dan usia matang dalam bekerja, sehingga diharapkan dapat bekerja dengan baik, yaitu lebih cepat, lebih tanggap dan lebih bertanggung jawab, serta memiliki kinerja yang tinggi sesuai dengan yang diharapkan. Berdasarkan tingkat pendidikan, paling banyak adalah pegawai yang berpendidikan Sarjana (S1) yaitu sebanyak 79 orang atau $63,7 \%$. Hal ini menggambarkan bahwa secara pendidikan para perangkat desa di Kabupaten Rokan Hulu tersebut memiliki jenjang pendidikan yang tinggi sehingga diharapkan dapat memberikan pemikiran yang baik dan memiliki pola kerja yang baik pula, berdasarkan pengalaman kerja paling banyak adalah pegawai yang sudah bekerja selama 1120 tahun yaitu sebanyak 71 orang atau $57,2 \%$. Hal ini menggambarkan bahwa para pegawai tersebut sudah tergolong memiliki banyak pengalaman dalam kegiatan rutinitas dan seluk-beluk pada kantor desa sehingga diharapkan lebih terampil dan profesional dalam bekerja, sehingga dapat bekerja dengan baik dengan memiliki rasa tanggung jawab yang tinggi.

\section{Evaluasi Model Pengukuran (Outer Model)}

Evaluasi model pengukuran atau outer model dilakukan untuk menilai validitas atau reliabilitas model. Outer model dengan indikator refleksif dievaluasi melalui Convergent Validity dan Discriminant Validity dari indikator pembentuk konstruk laten dan Composite Realiability untuk blok indikatornya (Latan \& Ghazali, 2012).

\section{Convergent Validity}

Rule of Thumb yang biasanya digunakan untuk menilai faktor loading yaitu harus $>0,7$ untuk penelitian yang bersifat confirmatory dan nilai loading faktor antara 0,6-0,7 masih dapat diterima untuk penelitian yang bersifat exploratory. Sedangkan untuk tahap pengembangan konstruk dan skala pengukuran atau pengembangan instrumen penelitian, nilai faktor loading 0,5 dianggap cukup (Hair $e t$ al., 2013). Penelitian ini melakukan reestimasi dua (2) kali dan membuang indikator yang memiliki nilai faktor loading dibawah 0,4-0,5. Nilai faktor loading secara rinci disajikan pada lampiran 2 .

\section{Discriminant Validity}


Studi Akuntansi \& Keuangan Indonesia

Uji validitas pada dinilai dengan Average Variance Extracted (AVE) untuk setiap konstruk dengan korelasi antar variabel konstruk di dalam model. Model memiliki nilai validitas discriminant cukup apabila nilai AVE lebih besar dari 0,5 (Chin 1997, dalam Latan \& Ghozali, 2012). Jika dilihat dari Tabel 2 maka semua Variabel nilai AVE berada diatas 0,5. Maka data dikatakan valid, sehingga dapat disimpulkan bahwa nilai Konstruk Loading Factor seluruh item pernyataan variabel penelitian ini memenuhi syarat uji validitas.

\section{Composite Reliability}

Uji realibilitas dilakukan untuk membuktikan akurasi, konsistensi dan ketepatan instrumen dalam mengukur konstruk. Untuk mengukur realibilitas suatu konstruk dengan indikator refleksif dilakukan dengan Composite Reliability. Rule of Thumb yang biasanya digunakan harus lebih besar dari 0,7 untuk penelitian bersifat confirmatory dan nilai $0,6-0,7$ masih dapat diterima untuk penelitian bersifat exploratory ( Latan dan Ghazali, 2012). Berdasarkan sajian data pada tabel 2, dapat diketahui bahwa nilai composite reliability semua variabel penelitian $>0,7$. Hasil ini menunjukkan bahwa masing-masing variabel telah memenuhi composite realibility sehingga dapat disimpulkan bahwa keseluruhan variabel memiliki tingkat realibilitas yang tinggi.

Tabel 2. Average Variance Extracted dan Composite Reliability

\begin{tabular}{|l|c|c|}
\hline & Average Variance Extracted (AVE) & Composite Reliability \\
\hline FRAUD-Y & 0,668 & 0,941 \\
\hline TEKANAN KETAATAN-X1 & 0,814 & 0,929 \\
\hline KOMPETENSI-X2 & 0,556 & 0,831 \\
\hline PERBUATAN TIDAK ETIS-X3 & 0,586 & 0,739 \\
\hline SPI-X4 & 0,649 & 0,914 \\
\hline BUDAYA ORGANISASI-X5 & 0,738 & 0,918 \\
\hline GAYA KEPEMIMPINAN-X6 & 0,579 & 0,845 \\
\hline
\end{tabular}

Sumber: Data olahan PLS,2020

\section{Evaluasi Model Struktural (Inner Model)}

Beberapa kriteria untuk mengukur inner model yaitu: goodness of fit dan uji hipotesis. RSquare untuk variabel Fraud adalah 0,561.

\section{Uji kelayakan model (goodness of fit)}


Fit model PLS dapat dilihat dari nilai nilai SMRM model, Model PLS dinyatakan telah memenuhi kriteria goodness of fit model jika nilai SRMR $<0,10$ dan model dinyatakan perfect fit jika nilai SRMR $<0,08$. Hasil uji goodness of fit model PLS menunjukkan bahwa nilai SRMR model PLS adalah sebesar 0,091. Oleh karena nilai SRMR model di bawah 0,10 maka model PLS ini dinyatakan fit, sehingga layak digunakan untuk menguji hipotesis penelitian.

\section{$\underline{\text { Uji Hipotesis }}$}

Tabel 3 menunjukkan hasil uji hipotesis model penelitian.

Tabel 3. Uji Hipotesis

\begin{tabular}{|l|r|r|l|}
\hline & \multicolumn{1}{|c|}{$\begin{array}{c}\text { Original } \\
\text { Sample }\end{array}$} & $\begin{array}{c}\text { T } \\
\text { Statistics }\end{array}$ & \multicolumn{1}{|c|}{ Hasil } \\
\hline Tekanan Ketaatan-X1 -> Fraud-Y & 0,410 & 6,073 & Diterima \\
\hline Kompetensi-X2 -> Fraud-Y & $-0,169$ & 2,784 & Diterima \\
\hline Perbuatan Tidak Etis-X3 -> Fraud-Y & 0,209 & 3,387 & Diterima \\
\hline Keefektifan SPI-X4 -> FRAUD-Y & $-0,344$ & 1,651 & Diterima \\
\hline Budaya Organisasi-X5 -> Fraud-Y & $-0,075$ & 0,380 & Ditolak \\
\hline Gaya Kepemimpinan-X6 -> Fraud-Y & $-0,136$ & 1,627 & Ditolak \\
\hline
\end{tabular}

Evaluasi untuk model struktural untuk menguji signifikansi konstruk menggunakan nilai t statistik dari masing-masing path. Nilai t statistic harus lebih besar dari 1.64 untuk hipotesis onetailed (Hair et al., 2008). Tabel 3 diatas menunjukkan nilai t statistik pengaruh ketaatan terhadap fraud sebesar 6,073 > 1,64 (one tailed) dan nilai path koefisien positif 0,410, yang berarti hipotesis 1 diterima yaitu tekanan ketaatan berpengaruh positif terhadap fraud. Hubungan antara kompetensi dan kecurangan dalam pengelolaan dana desa berpengaruh negatif signifikan dengan nilai t statistik 2,78 $>1,64$ (one tailed) dan nilai path koefisien negatif $-0,169$, Hal ini menunjukkan bahwa hipotesis 2 diterima. Variabel perbuatan tidak etis menunjukkan hubungan positif signifikan dengan kecurangan pengelolaan dana desa ( $\mathrm{t}$ statistik sebesar 3,387 > 1,64 (one tailed) dan nilai path koefisien positif 0,209). Hasil ini menunjukkan hipotesis 3 diterima.

Hasil pengujian berikutnya adalah antara keefektivan sistem pengendalian intern dan kecurangan pengelolaan dana desa yang menunjukkan hubungan negatif signifikan (nilai t statistik sebesar $1,651>1,64)($ one tailed). Ini berarti hipotesis empat diterima. Selanjutnya hubungan antara 
Studi Akuntansi \& Keuangan Indonesia

budaya organisasi menunjukkan hubungan tidak signifikan (t statistik $0,380<1,64$ ). Hasil ini menunjukkan hipotesis lima ditolak yang berarti bahwa variabel budaya organisasi tidak memiliki pengaruh terhadap kecurangan pengelolaan dana desa. Hasil terakhir yaitu antara gaya kepemimpinan dan kecurangan pengelolaan dana desa yang menunjukkan hasil tidak signifikan (t statistic $1,627<1,64)$, sehingga hipotesis ke enam tidak dapat diterima. Output hasil pengujian model struktural secara lengkap dapat dilihat pada lampiran 3.

\section{Diskusi}

\section{Tekanan Ketaatan dan Fraud}

Hasil penelitian menunjukkan bahwa variabel tekanan ketaatan memiliki pengaruh positif terhadap kecurangan pengelolaan dana desa. Hal ini berarti semakin besar tekanan yang diterima oleh seorang pegawai maka tindakan untuk melakukan fraud juga akan semakin tinggi. Permasalahan yang timbul disini adalah seorang pegawai akan memutuskan untuk berperilaku curang (fraud) karena adanya desakan baik dari diri pribadi, organisasi, maupun dari luar. Rafinda (2013) menyebutkan bahwa perilaku atasan atau tekanan yang diberikan atasan terbukti dapat mempengaruhi perilaku seluruh bawahannya. Atasan yang berperilaku etis akan menuntun bawahannya untuk berperilaku etis dan sebaliknya. Selain itu, Sofyani dan Pramita (2014) juga menemukan bahwa kondisi dimana terdapat tekanan ketaatan untuk melakukan kecurangan cenderung akan menjadikan seseorang bertindak memanipulasi laporan.

\section{Kompetensi dan Fraud}

Temuan penelitian ini menunjukkan bahwa bahwa kompetensi memiliki pengaruh negatif terhadap kecurangan pengelolaan dana desa, Berdasarkan penelitian yang dilakukan oleh Basirruddin dan Amin (2014) yang mengatakan tingkat pendidikan rendah yang dimiliki oleh aparatur desa menjadi hambatan dalam mengelola keuangan desa sehingga berpotensi terjadinya kecurangan (fraud). Sehingga Basirruddin dan Amin (2014) menyimpulkan bahwa tingkat kompetensi yang rendah bagi seorang pegawai akan meningkatkan kecurangan yang terjadi. Diharapakan dengan kompetensi yang memadai aparat desa bisa mencegah fraud sehingga tindak kecurangan dana desa berkurang. Bila kompetensi berupa pengetahuan, kemampuan dan sikap/attitude dipenuhi oleh 
Studi Akuntansi \& Keuangan Indonesia

seorang pegawai, maka akan membuat para aparatur desa ini bisa memilah tindakan yang akan dilakukan atau dihindari demi tercapainya penggunaan dana desa yang efektif dan efisien.

\section{Perbuatan Tidak Etis dan Fraud}

Berdasarkan hasil penelitian menunjukkan bahwa perilaku tidak etis memiliki pengaruh positif terhadap kecurangan pengelolaan dana desa. Ini berarti semakin tinggi tingkat perilaku yang tidak etis akan meningkatkan juga tingkat kecurangan yang terjadi. Berbagai kajian dan penyampaian fakta, seperti oleh Beaulieu \& Reinstein (2010) menunjukkan bahwa perilaku tidak etis dalam bentuk penyalahgunaan wewenang dan kekuasaan, kedudukan, dan sumberdaya perusahaan, mendorong manajemen melakukan kecurangan akuntansi. Jika perilaku yang ditunjukan oleh manajemen cenderung tidak etis maka dapat menyebabkan terjadinya tindakan kecurangan akuntansi. Dengan kata lain, semakin tinggi perilaku tidak etis maka semakin tinggi pula tindakan kecurangan akuntansinya.

\section{Keefektifan Sistem Pengendalian Internal Dan Fraud}

Hasil penelitian membuktikan bahwa keefektifan sistem pengendalian internal memiliki pengaruh negatif terhadap kecurangan pengelolaan dana desa. Hal ini menunjukkan bahwa semakin efektifnya sistem pengendalian internal yang ada di kantor desa tersebut akan mengurangi tindak kecurangan dana desa yang terjadi. Sistem pengendalian internal yang efektif diharapkan mampu mengurangi adanya tindakan menyimpang yang dilakukan oleh manajemen. Manajemen cenderung melakukan tindakan menyimpang untuk memaksimalkan keuntungan pribadi. Salah satu contoh tindakan menyimpang yaitu kecenderungan melakukan kecurangan akuntansi. Peluang yang besar membuat kecenderungan kecurangan akuntansi lebih sering terjadi. Peluang tersebut dapat dikurangi dengan sistem pengendalian internal yang baik (Mustika et al., 2016). Hal ini sejalan dengan penelitian terdahulu yang dilakukan oleh Wilopo (2006).

\section{Budaya Organisasi Internal dan Fraud}

Hasil temuan membuktikan bahwa budaya organisasi tidak memiliki pengaruh terhadap kecurangan pengelolaan dana desa. Hasil penelitian ini sejalan dengan penelitian yang dilakukan Apriadi dan Fachriyah (2014) dan Kurrohman \& Widyayanti (2018) yang menyatakan bahwa tidak 
Studi Akuntansi \& Keuangan Indonesia

terdapat pengaruh budaya organisasi terhadap tindak kecuranggan di Instansi Pemerintahan. Zulkarnain (2013) juga menyatakan bahwa ketidakberpengaruhan antara dua variabel ini bisa disebabkan budaya organisasi yang tumbuh di dinas-dinas sudah baik, sehingga menyebabkan para pegawai terbiasa dan menyebabkan budaya bukan merupakan faktor yang dapat mempengaruhi terjadinya tindak kecurangan. Zulkarnain (2013) lebih lanjut menjelaskan bahwa jika dilihat dari para pelaku fraud, sebagian besar tersangka korupsi barasal dari kalangan menengah keatas. Fenomena tersebut disebabkan para pejabat memiliki tuntutan gaya hidup yang mewah. Sehingga menuntut individu untuk melakukan tindakan kecurangan (fraud), sementara hasil penelitian menunjukkan bahwa di Rokan Hulu kondisi kerja sudah baik, maka tidak ada tuntutan atau tidak pernah terfikir untuk melakukan fraud. Kondisi ini membuat budaya organisasi tidak terlalu memberikan dampak yang nyata pada tingkat fraud yang terjadi. Artinya, budaya organisasi bukan variabel yang bisa menjelaskan fraud. Hasil penelitian ini sesuai dengan Lina (2014) yang menunjukkan bahwa budaya organisasi tidak berpengaruh signifikan terhadap fraud.

\section{Gaya Kepemimpinan dan Fraud}

Sama halnya dengan budaya organisasi, gaya kepemimpinan menunjukkan hasil tidak berpengaruh signifikan terhadap kecurangan pengelolaan dana desa. Gaya kepemimpinan yang diterapkan di masing- masing kantor Desa di Rokan Hulu sudah dalam tahap bagus, yang artinya Kepala Desa sebagai pemimpin dalam pemerintahan desa sudah berperan secara efektif dalam merencanakan, mengatur, mengorganisasikan, dan menentukan arah dan tujuan organisasi. Hal ini dapat ditunjukkan dari data jawaban koresponden, memperlihatkan bahwa nilai rata-rata jawaban responden sebesar 3,69. Nilai tersebut termasuk dalam kategori "Setuju/Baik". Hal ini menunjukkan bahwa tingkat arogansi pimpinan kecil yang berpotensi tidak akan menimbulkan masalah arogan dikemudian hari. Hal ini bisa menunjukkan bahwa tinggi rendahnya fraud tidak dipengaruhi oleh gaya kepemimpinan di desa

\section{Kesimpulan, Implikasi, dan Keterbatasan}


Bedasarkan hasil penelitian dapat ditarik kesimpulan bahwa stimulus yang diukur dengan tekanan ketaatan, capability yang diproksikan dengan kompetensi, collusion yang diukur dengan perbuatan yang tidak etis dan opportunity yang diproksikan dengan keefektifan sistem pengendalian internal berpengaruh terhadap fraud yang terjadi pada pengelolaan dana desa di Kabupaten Rokan Hulu. Sementara Razionalitation yang diukur dengan budaya organisasi dan ego yang diukur dengan gaya kepemimpinan tidak berpengaruh terhadap fraud yang terjadi pada pengelolaan dana desa di Kabupaten Rokan Hulu.

Hasil penelitian ini memberikan kontribusi bagi perkembangan teori khusunya dalam fraud, dimana dalam penelitian ini peneliti meneliti menggunakan teori baru yaitu Hexagon Theory yaitu teori yang menambahkan 1 variabel baru yaitu kolusi. Diharapkan dengan penelitian ini maka akan membantu peneliti-peneliti selanjutnya yang akan meneliti fraud dari segi Hexagon Theory. Karena peneliti menyadari literatur yang terlalu sedikit mengenai Hexagon Theory ini. Hasil penelitian ini juga menegaskan bahwa ada beberapa hal yang dapat menyebabkan tindakan kecurangan terjadi, seperti keefektifan SPI. SPI terbukti secara data dapat mengurangi fraud, oleh sebab itu hasil penelitian ini memberikan implikasi kepada aparatur desa untuk secara bersama-sama dapat meningkatkan secara optimal SPI yang ada di masing-masing kantor desa sehingga akan meminimalisir kesempatan negatif yang muncul dalam pengelolaan dana desa. Hasil penelitian ini juga menegaskan bahwa kemampuan yang diukur oleh kompetensi dapat mencegah terjadinya kecurangan dalam pengelolaan dana desa, oleh sebab itu sebaiknya aparatur desa bisa meningkatkan kemampuan mereka bisa melalui workshop atau seminar- seminar yang diadakan oleh pemerintah daerah setempat.

Penelitian ini tidak luput dari keterbatasan. Penelitian ini dilakukan hanya di lingkup pemerintah daerah Kabupaten Rokan Hulu, sehingga hasil penelitian ini lebih menggambarkan situasi secara lokal, penelitian selanjutnya akan lebih baik menggunakan data populasi yang luas, tidak hanya mencakup satu kabupaten saja, sehingga kesimpulannya bisa digunakan jika ditujukan untuk populasi yang luas. Penelitian ini murni dilakukan dengan metode survei dan belum dilengkapi dengan metode wawancara sehingga kemungkinan jawaban responden belum sepenuhnya menggambarkan keadaan 
Studi Akuntansi \& Keuangan Indonesia

yang sebenarnya. Penelitian selanjutnya sebaiknya tidak hanya menggunakan metode melalui

kuesioner, tetapi juga dengan melakukan wawancara langsung kepada responden sehingga hasil yang

didapat lebih akurat dan lebih tepat sasaran.

\section{Daftar Pustaka}

Adnyani, N., Atmadja, A.T., dan Herawati, N.T. (2014). Pengaruh Skeptisme Profesional Auditor, Independensi, dan Pengalaman Auditor Terhadap Tanggungjawab Auditor Dalam Mendeteksi Kecurangan Dan Kekeliruan Laporan Keuangan. JIMAT (Jurnal Ilmiah Mahasiswa Akuntansi) Undiksha, 2(1), 1-11.

Apriadi, R.N., dan Fachriyah, N. (2014). Determinan Terjadinya Fraud di Instansi Pemerintahan. Jurnal Ilmiah Mahasiswa FEB, 3(1), 1-25.

Basirruddin, M., \& Amin, M. (2014). Peran Pemerintahan Desa dalam Pengelolaan Keuangan Desa Alai Kecamatan Tebing Tinggi Barat Kabupaten Kepulauan Meranti Tahun 2012. Jurnal Online Mahasiswa (JOM) Bidang Ilmu Sosial dan Ilmu Politik, 1(2), 1-11.

Beaulieu, P., \& Reinstein, A. (2010). Belief perseverance among accounting practitioners regarding the effect of non-audit services on auditor independence. Journal of Accounting and Public Policy, 29(4), 353-373.

Danuta, K. S. (2017). Pengadaan Secara Elektronik (E-Procurement) untuk Mencegah Fraud pada Proses Pengadaan Barang dan Jasa Pemerintah Kota Yogyakarta. Yogyakarta: Universitas Gadjah Mada.

Edison, E., Anwar, Y., \& Komariyah, I. (2016). Manajemen sumber daya manusia. Bandung: Alfabeta.

Hair, J. F., Ringle, C. M., \& Sarstedt, M. (2013). Partial least squares structural equation modeling: Rigorous applications, better results and higher acceptance. Long range planning, 46(1-2), 1-12.

Hair, J.F., Anderson, R.R., Tatham, R.L., \& Black, W.C. (2008). Multivariate Data Analysis, $7^{\text {th }}$ ed. Prentice Hall Publisher, New Jersey.

Hartoyo, F. (2016). Analisis Pentagon Fraud Dalam Mendeteksi Fraudulent Financial Reporting pada Perusahaan Manufaktur yang Terdaftar di Bursa Efek Indonesia Periode 2011-2015. Skripsi (tidak diterbitkan). Universitas Katolik Widya Mandala, Surabaya.

Horwath, C. (2011). Accounting Standart Update. http://www.crowehorwath.net/id/. Diakses Juni 2019.

Kementrian Keuangan Republik Indonesia.(2016). Kebijakan Umum Dana Desa TA 2016. dalam kemenkopmk.go.id [online] (10 Oktober 2019). Diakses daricisdi.org/files/53a4d07ef0deb6 26b0f0d186 dd6f27742834a016.pdf. (Diakses pada tanggal 03 Oktober 2019 pukul 20.15 WIB)

Kementrian Keuangan.2018. Buku Dana Desa. 2018. https://www.kemenkeu .go.id/media/6750/buku-sakudana-desa.pdf(Diakses pada tanggal 03 Oktober 2019 pukul 20.15 WIB).

Kurrohman, T., \& Widyayanti, P. (2018). Analisis Faktor-Faktor yang Mempengaruhi Kecenderungan Kecurangan (Fraud) di Perguruan Tinggi Keagamaan Islam Negeri. Journal of Applied Managerial Accounting, 2(2), 245-254.

Latan, H., \& Ghozali, I. (2012). Partial Least Square "Konsep, Teknik dan Aplikasi” SmartPLS 2.0 M3. Semarang: Badan Penerbit Universitas Diponegoro.

Lina, D. (2014). Analisis pengaruh kepemimpinan dan budaya organisasi terhadap kinerja pegawai dengan sistem reward sebagai variabel moderating. JRAB: Jurnal Riset Akuntansi \& Bisnis, 14(1), 77-97.

Mayhew, B. W., \& Murphy, P. R. (2014). The impact of authority on reporting behavior, rationalization and affect. Contemporary Accounting Research, 31(2), 420-443.

Montgomery, D. D., Beasley, M. S., Menelaides, S. L., \& Palmrose, Z. V. (2002). Auditors' new procedures for detecting fraud. Journal of Accountancy, 193(5), 63.

Mustika, D., Hastuti, S., \& Heriningsih, S. (2016). Analisis faktor-faktor yang mempengaruhi kecenderungan kecurangan (fraud): Persepsi pegawai dinas Kabupaten Way Kanan Lampung. Simposium Nasional Akuntansi XIX. Lampung, 1-22.

Pramudita, A. (2013). Faktor-Faktor Yang Mempengaruhi Terjadinya Fraud Di Sektor Pemerintahan.(Persepsi Pegawai Pada Dinas Se-Kota Salatiga) (Doctoral dissertation, Universitas Negeri Semarang). 
Studi Akuntansi \& Keuangan Indonesia

Rafinda, A., Pramuka, B. A., \& Kusuma, P. D. I. (2013). The Trend And Variation Of Intellectual Capital Disclosure At Bank Industries In Europe. Journal of Economics, Business, \& Accountancy Ventura, 16(1), 105-118.

Robbins, S. P., \& Timothy A. J. 2011. Perilaku Organisasi. Edisi kedua belas (ed.12). Penerjemah Diana Angelica. Jakarta: Salemba Empat.

Sihombing, K. S., \& Rahardjo, S. N. (2014). Analisis Fraud Diamond dalam Mendeteksi Financial Statement Fraud: Studi Empiris pada Perusahaan Manufaktur yang Terdaftar di Bursa Efek Tahun 2010-2012. Skripsi Universitas Diponegoro, tidak dipublikasikan.

Singleton, T. W., Singleton, A. J., Bologna, G. J., \& Lindquist, R. J. (2006). Fraud auditing and forensic accounting. John Wiley \& Sons.

Skousen, C. J., Smith, K. R., \& Wright, C. J. (2009). Detecting and predicting financial statement fraud: The effectiveness of the fraud triangle and SAS No. 99. In Corporate governance and firm performance. Emerald Group Publishing Limited.

Sofyani, H dan Y. D. Pramita. (2013). Otoritas Atasan, Retaliasi dan Locus Of Control Sebagai Faktor Faktor yang Memengaruhi Perilaku Manipulasi Laporan Realisasi Anggaran. Jurnal Reviu Akuntansi dan Keuangan, 3 (2), 415-506.

Sumbayak, J. S. (2017). Pengaruh Keadilan Organisasi, Sistem Pngendalian Intern, Komitmen Organisasi dan Gaya Kepemimpinan Terhadap Kecurangan (Fraud). Jurnal Online Mahasiswa Fakultas Ekonomi (JOM Fekon), 4(1), 3168-3182.

Tang, T. L. P., \& Chiu, R. K. (2003). Income, money ethic, pay satisfaction, commitment, and unethical behavior: Is the love of money the root of evil for Hong Kong employees?. Journal of business ethics, 46(1), 13-30.

Tuanakotta, T. M. (2010). Akuntansi Forensik dan Audit Investigatif. Salemba Empat: Jakarta.

Ulfah, M., Nuraina, E., \& Wijaya, A. L. (2017). Pengaruh Fraud Pentagon dalam Mendeteksi Fraudulent Financial Reporting (Studi Empiris pada Perbankan di Indonesia Yang Terdaftar di Bei. In FIPA: Forum Ilmiah Pendidikan Akuntansi, 5(1), 399-418.

Vousinas, G. (2019). Advancing theory of fraud: the S.C.O.R.E. model. Journal of Financial Crime, 26(1), 372381, https://doi.org/10.1108/JFC-12-2017-0128

Wilopo, W. (2006). Analisis Faktor-faktor yang Berpengaruh Terhadap Kecenderungan Kecurangan Akuntansi: Studi pada Perusahaan Publik dan Badan Usaha Milik Negara di Indonesia. The Indonesian Journal of Accounting Research, 9(3).

Wulandari, S., dan Zaky, A. (2015). Determinan Terjadinya Fraud di Instansi Pemerintahan (Persepsi pada Pegawai BPK RI Perwakilan Provinsi NTB). Jurnal Ilmiah Mahasiswa FEB Universitas Brawijaya, 3(2), 1-32.

Yendrawati, R., \& Mukti, D. K. (2015). Pengaruh gender, pengalaman auditor, kompleksitas tugas, tekanan ketaatan, kemampuan kerja dan pengetahuan auditor terhadap audit judgement. Asian Journal of Innovation and Entrepreneurship, 4(01), 1-8.

Yesiarini, M., dan Rahayu, I. (2016). Analisis Fraud Diamond Dalam Mendeteksi Financial Statement Fraud (Studi Empiris pada Perusahaan LQ-45 yang Terdaftar di Bursa Efek Indonesia Tahun 2010-2014). Simposium Nasional Akuntansi XIX. Lampung.

Zimbelman, M. F., Albrecht, C. C., Albrecht, W. S., \& Albrecht, C. O. (2014). Akuntansi Forensik. Jakarta: Salemba Empat.

Zulkarnain, R. M. (2013). Analisis Faktor yang Mempengaruhi Terjadinya Fraud pada Dinas Kota Surakarta. Accounting Analysis Journal, 2(2), 125-131. 


\section{Lampiran 1. Kuesioner penelitian (Variabel Laten dan Variabel Indikator)}

A. Pertanyaan Kuesioner

\begin{tabular}{|c|c|c|c|c|c|c|}
\hline No. & PERNYATAAN & SS & $\mathbf{S}$ & $\mathbf{R R}$ & TS & STS \\
\hline \multicolumn{7}{|c|}{ A. Tekanan atasan/ otorisasi atasan } \\
\hline 1 & $\begin{array}{l}\text { Saya tidak bisa menuruti perintah atasan yang menyimpang } \\
\text { dari standar profesi. }\end{array}$ & & & & & \\
\hline 2 & $\begin{array}{l}\text { Saya tidak akan menaati perintah atasan karena saya ingin } \\
\text { terus bekerja secara aman di Kantor walaupun harus } \\
\text { bertentangan dengan standar akuntasi atau aturan hukum. }\end{array}$ & & & & & \\
\hline 3 & $\begin{array}{l}\text { Saya tidak akan mengikuti perintah dari atasan untuk } \\
\text { berperilaku menyimpang dari pekerjaan yang sudah } \\
\text { ditargetkan. }\end{array}$ & & & & & \\
\hline 4 & $\begin{array}{l}\text { Saya akan menentang perintah atasan dan memilih keluar dari } \\
\text { pekerjaan saya jika saya dipaksa untuk melakukan hal yang } \\
\text { bertentangan dengan standar profesi. }\end{array}$ & & & & & \\
\hline 5 & $\begin{array}{l}\text { Saya akan menentang perintah atasan karena saya ingin } \\
\text { menegakkan profesional }\end{array}$ & & & & & \\
\hline No. & PERNYATAAN & SS & $\mathbf{S}$ & $\mathbf{R R}$ & TS & STS \\
\hline \multicolumn{7}{|c|}{ B. Kompetensi } \\
\hline 1 & $\begin{array}{l}\text { Saya mempunyai inisiatif untuk belajar tentang pekembangan } \\
\text { arus informasi seperti internet }\end{array}$ & & & & & \\
\hline 2 & $\begin{array}{l}\text { Dengan pengetahuan yang saya miliki, saya dapat } \\
\text { menyelesaikan tugas-tugas pekerjaan dengan baik dengan } \\
\text { tepat waktu }\end{array}$ & & & & & \\
\hline 3 & $\begin{array}{l}\text { Kompetensi yanmg saya miliki membuat saya merasakan } \\
\text { percaya diri untuk menyelesaikan tugas pekerjaan dengan } \\
\text { kualitas yang baik }\end{array}$ & & & & & \\
\hline 4 & Saya percaya diri bila ditempatkan pada tugas pekerjaan yang & & & & & \\
\hline
\end{tabular}




\begin{tabular}{|c|c|c|c|c|c|c|}
\hline & tidak sesuai dengan kompetensi yang saudara miliki & & & & & \\
\hline 5 & $\begin{array}{l}\text { Saya tidak merasa rendah diri bila mengalami keagagalan } \\
\text { dalam menjalankan tugas pekerjaan }\end{array}$ & & & & & \\
\hline 6 & $\begin{array}{l}\text { Saya mampu berkomunikasi dengan baik terhadap sesame } \\
\text { rekan kerja dilingkungan kantor }\end{array}$ & & & & & \\
\hline 7 & $\begin{array}{l}\text { Saya siap membantu rekan kerja yang memerlukan bantuan } \\
\text { untuk menyelsaikan pekerjaan ataupun masalah-masalah lain } \\
\text { diluar pekerjaan }\end{array}$ & & & & & \\
\hline \multicolumn{7}{|c|}{ C. Perilaku Tidak Etis } \\
\hline 1 & $\begin{array}{l}\text { Saya mengetahui bahwa menyuruh orang lain untuk } \\
\text { melakukan apa yang saya inginkan untuk menguntungkan diri } \\
\text { sendri adalah hal yang salah }\end{array}$ & & & & & \\
\hline 2 & $\begin{array}{l}\text { Di tempat saya bekerja, akan ada yang menegur secara } \\
\text { langsung apabila ada yang melanggar peraturan }\end{array}$ & & & & & \\
\hline 3 & $\begin{array}{l}\text { Di tempat saya bekerja, pegawai sadar bahwa membebankan } \\
\text { pekerjaan ke pegawai lain merupakan hal yang salah }\end{array}$ & & & & & \\
\hline 4 & $\begin{array}{l}\text { Di tempat saya bekerja, pegawai harus melakukan semua } \\
\text { pekerjaan yang dibebankan kepadanya dan tidak boleh } \\
\text { memilik pekerjaan. }\end{array}$ & & & & & \\
\hline No. & & SS & $\mathbf{S}$ & $\mathbf{R R}$ & TS & STS \\
\hline
\end{tabular}

D. KEEFEKTIFAN SISTEM PENGENDALIAN INTERNAL

\begin{tabular}{|c|l|l|l|l|l|l|}
\hline 1 & Pemerintah desa memiliki struktur organisasi yang jelas & & & & & \\
\hline 2 & $\begin{array}{l}\text { Pimpinan telah melakukan analisis risiko secara lengkao dan } \\
\text { menyeluruh terhadap kemungkinan timbulnya pelanggaran } \\
\text { sistem pengelolaan dana desa }\end{array}$ & & & & & \\
\hline 3 & $\begin{array}{l}\text { Kebijakan dan prosedur pengamanan fisik atau aset telah } \\
\text { ditetapkan dan diimplementasikan dengan baik }\end{array}$ & & & & \\
\hline 4 & $\begin{array}{l}\text { pemerintah desa telah menyediakan alat pendukung untuk } \\
\text { berbagai transaksi dan penyajian laporan keuangan seperti } \\
\text { perangkat keras (hardware) }\end{array}$ & & & & \\
\hline 5 & $\begin{array}{l}\text { Kantor desa selalu menindaklanjuti setiap hasil temuan/ reviu } \\
\text { dan saran yang diberikan oleh BPK/ Inspektorat }\end{array}$ & & & & \\
\hline 6 & $\begin{array}{l}\text { Pimpinan selalu mereviu dan mengevaluasi temuan yang } \\
\text { menunjukkan adanya kelemahan dan perlu perbaikan }\end{array}$ & & & & \\
\hline
\end{tabular}

\section{E. Gaya Kepemimpinan}

\begin{tabular}{|c|l|l|l|l|l|l|}
\hline 1 & $\begin{array}{l}\text { Atasan saya selalu memberikan arahan langsung kepada } \\
\text { bawahan dalam rangka pelaksanaan pekerjaan }\end{array}$ & & & & \\
\hline 2 & $\begin{array}{l}\text { Atasan selalu memastikan adanya pedoman kerja pada } \\
\text { masing-masing bagian kerja yang melaksanakan tugas } \\
\text { pokoknya }\end{array}$ & & & & & \\
\hline 3 & $\begin{array}{l}\text { Atasan memberikan kesempatan kepada pegawai untuk } \\
\text { mendiskusikan masalah-masalah yang terkait dengan } \\
\text { pekerjaan. }\end{array}$ & $\begin{array}{l}\text { Atasan menerima dan memperhatikan masukan dan informasi } \\
\text { dari bawahan dalam pengambilan keputusan }\end{array}$ & & & & \\
\hline 5 & $\begin{array}{l}\text { Atasan saya memberikan kesempatan kepada bawahan untuk } \\
\text { mengembangkan karir }\end{array}$ & & & & \\
\hline 6 & $\begin{array}{l}\text { Atasan saya memberikan tugas pekerjaan yang sesuai dengan } \\
\text { bidang dan kemampuan bawahan }\end{array}$ & & & & \\
\hline
\end{tabular}
bidang dan kemampuan bawahan

A. Kecurangan (Fraud)

Di tempat saya bekerja pencatatan tanggal transaksi sering

1 tidak sesuai dengan waktu transaksi yang sebenarnya.

Di tempat saya bekerja pernah mencatat biaya-biaya fiktif

2 (biaya transportasi atau kebutuhan lain) dalam melaksanakan pekerjaan.

3 Di tempat saya bekerja melaporkan pengungkapan atas 
Studi Akuntansi \& Keuangan Indonesia

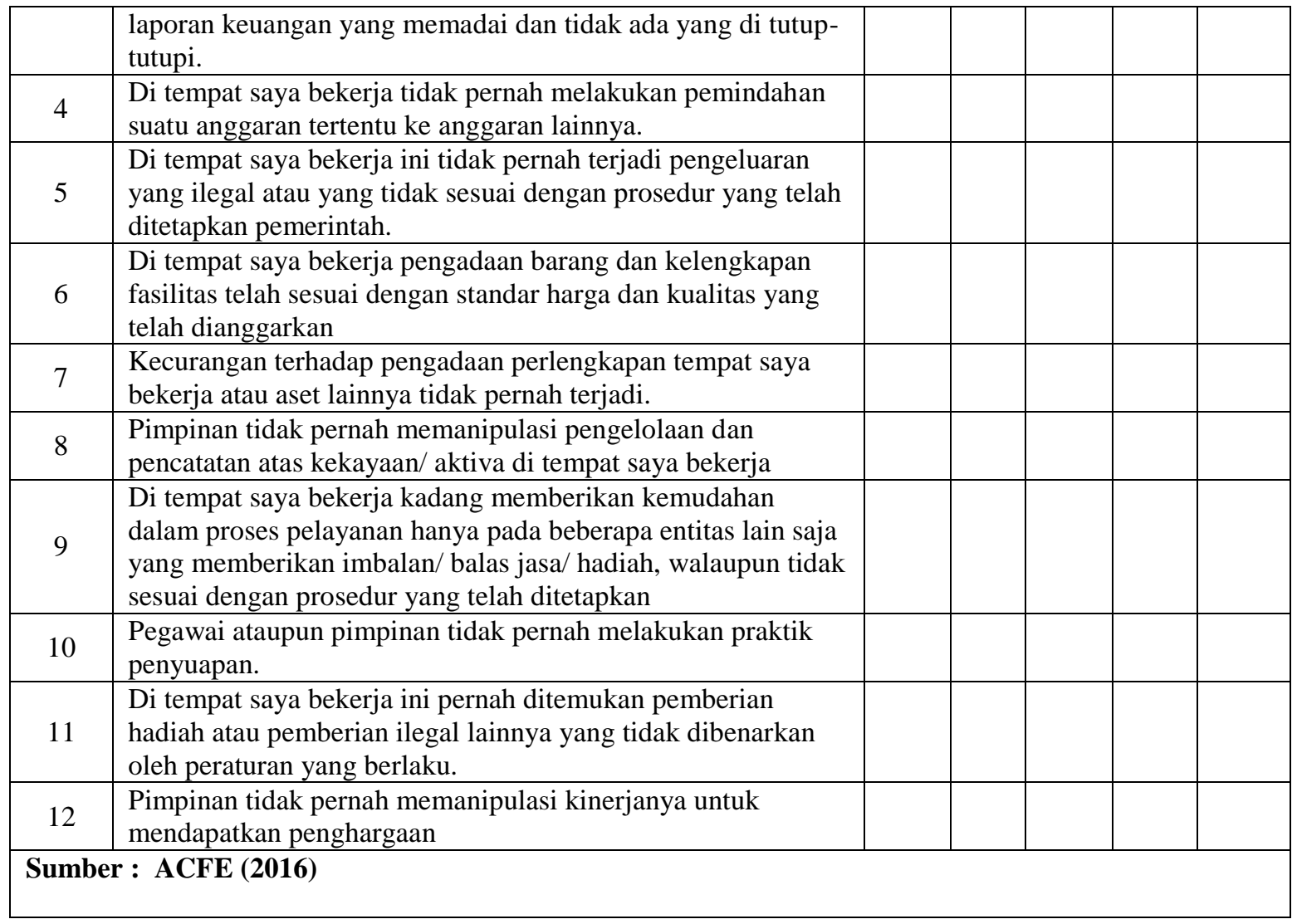

Lampiran 2. Indicator Loadings

\begin{tabular}{|l|r|r|l|l|l|l|l|}
\hline & BO-X5 & $\begin{array}{l}\text { FRAUD- } \\
\text { Y }\end{array}$ & GK-X6 & KMPT-X2 & PTE-X3 & SPI-X4 & TK-X1 \\
\hline BO2 & 0,920 & & & & & & \\
\hline BO3 & 0,887 & & & & & & \\
\hline BO4 & 0,825 & & & & & & \\
\hline BO5 & 0,798 & & & & & & \\
\hline F1 & & 0,814 & & & & & \\
\hline F2 & & 0,845 & & & & & \\
\hline F3 & & 0,673 & & & & & \\
\hline F4 & & 0,885 & & & & & \\
\hline F5 & & 0,835 & & & & & \\
\hline F6 & & 0,863 & & & & & \\
\hline F7 & & 0,785 & & & & & \\
\hline F8 & & 0,822 & & & & & \\
\hline GK1 & & & 0,733 & & & & \\
\hline GK2 & & & 0,694 & & & & \\
\hline GK5 & & & 0,754 & & & & \\
\hline GK6 & & & & & & \\
\hline
\end{tabular}


Studi Akuntansi \& Keuangan Indonesia

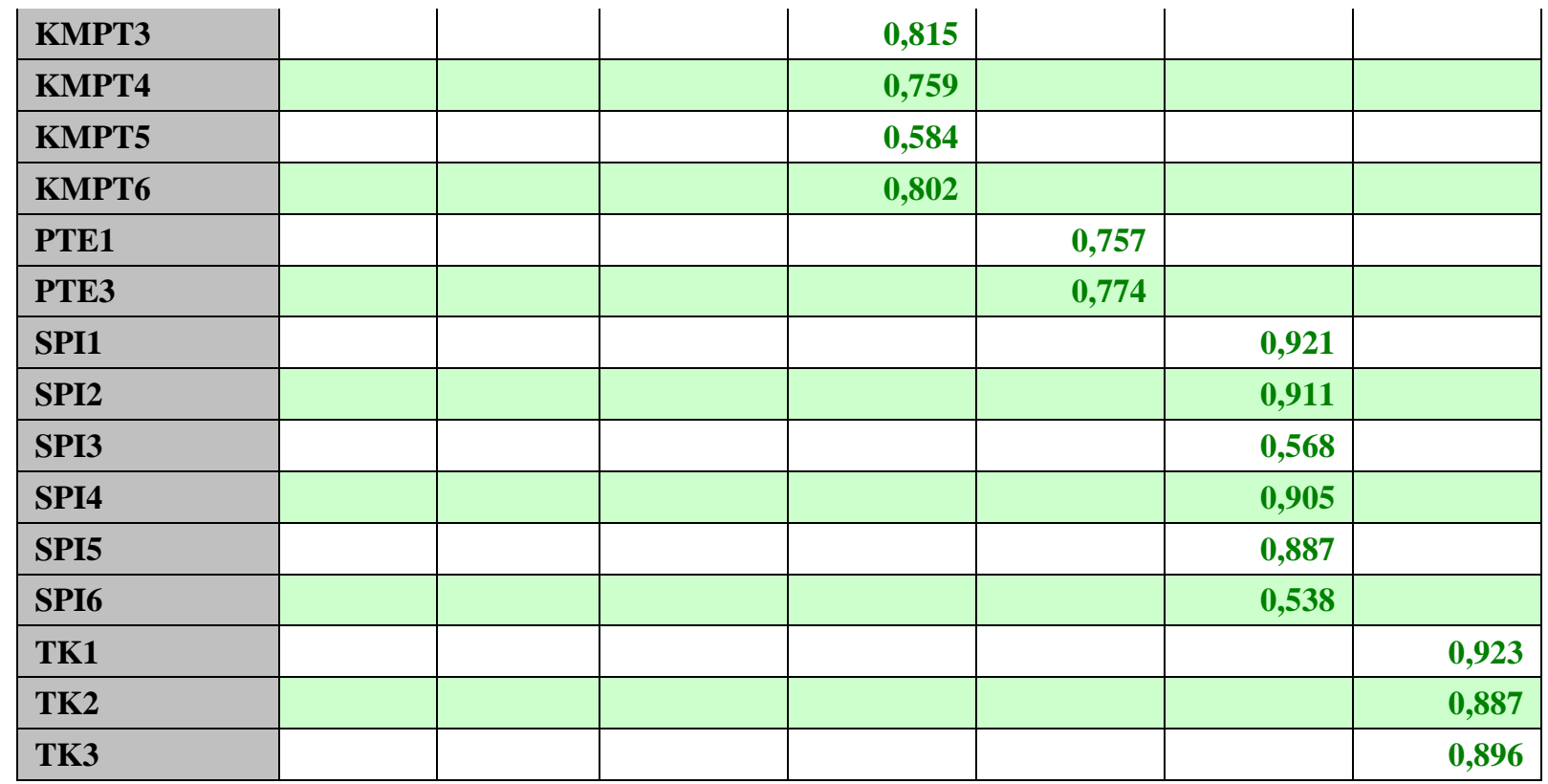

Lampiran 3. Output model struktural dan nilai t statistik 
Studi Akuntansi \& Keuangan Indonesia

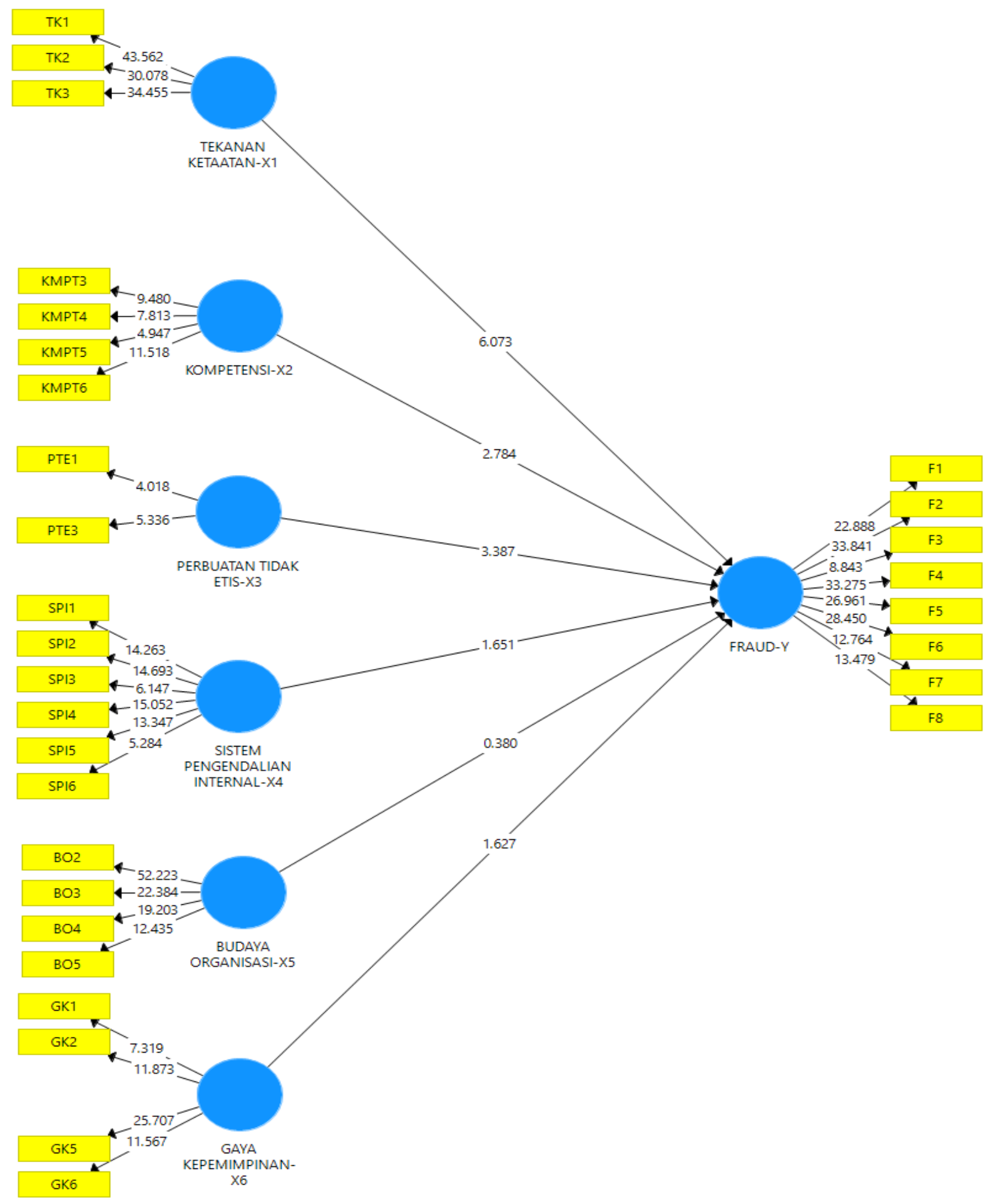

